\title{
Tuber Crops Based Integrated Farming System Studies in Bastar and Kondagaon Districts of Chhattisgarh
}

\author{
Deo Shankar*, Chetna Banjare and M.K. Sahu
}

\author{
Shaheed Gundadhoor College of Agriculture and Research Station (Indira Gandhi Krishi \\ Vishwavidyalaya) Jagdalpur, Bastar 494005 (Chhattisgarh), India
}

*Corresponding author

\section{A B S T R A C T}

\section{Keywords}

Farming system, Tuber crops,

Integrated, Bastar, Fish components, B: C ratio

\section{Article Info}

\section{Accepted:}

10 August 2018 Available Online:

10 September 2018
An investigation for tuber crops based farming system studies under the project Tribal Sub Plan, AICRP on Tuber Crops was conducted with different components of farming conducted during the year 2012-13 to 2015-16 at two locations of Bastar division of Chhattisgarh. The Location-1 was Village: Gumiyapal, Tokapal Block, Bastar District, Chhattisgarh State (N $19^{\circ}$ 07.181' and E 81 '50.905'; 506 msl) and Location -2 was Village: Tatirash, Keshkal Block, Kondagaon District, Chhattisgarh State (N 19 $59.961^{\prime}$ and E 081 $35.427^{\prime}$; 644 msl). The Socioeconomic profiles of the farmers of both locations were recorded before and after intervention of the farming system studies. After the intervention of tuber crops based integrated farming system in the farmer's field in Gumiyapal village, the farmers gross and net income increased to Rs 5,33,110/- and Rs $403720 \mathrm{ha}^{-1}$, respectively. The increase in income was due to integration of tuber crops, fruit crops, fish, poultry and ducks along with cereals and pulses. The gross and net income increased 463 and $610 \%$ respectively after intervention of tuber crops based integrated farming system. The B: C ratio increased from 1.56 to 4.12 . The employment generation increased from 199 to 261 man days. After the intervention of tuber crops based integrated farming system in the farmer's field in Tatirash village, the farmers gross and net income increased to Rs 5,28,660/- and Rs 3,97,960/ha, respectively. The gross and net income increased 397 and $447 \%$ respectively after intervention of tuber crops based integrated farming system. The B: C ratio increased from 2.18 to 4.04 . Under the farming system studies different crop component, animal component, fruit crops component has been tested at field of tribal farmers at village- Gumiyapal (Tokapal, Bastar) and Tatirash (Keshkal, Kondagaon). Under the crops component Amorphophallus/Zimikand given highest $\mathrm{BC}$ ratio 1: 3.35 followed by Dioscorea bulbifera (1:3.20) and Colocasia (Bunda) (1:2.75) as compare to other crops. The employment generation increased from 203 to 263 man days. However, more than additional employment, spread of employment through-out the year was attained in tuber crops based integrated farming system. Tuber crops based farming system is an integrated approach to farming as compared to monoculture. This model could increase land productivity, income of the farmers, balance nutrition, employment and sustainability of the farmer. This could be a model to attract and retain present generation farmers who are very migrating to urban areas. However, we need to frame policies to help the small farmers to diversify their activities towards both on-farm and off-farm activities for enhanced sustainability and productivity. The model developed has the potential to transform the tribal region of Chhattisgarh, especially the Bastar and Kondagaon districts. 


\section{Introduction}

India is the second most populous country in the world. With the population growth rate of over two per cent, the population is increasing year after year. Therefore, the challenge of meeting the basic requirements of this increasing population is a major concern. Agriculture is the backbone of India. More than $60 \%$ of population steel depends on agriculture. Presently the food production of India is $260 \mathrm{mt}$ and the rate of increase in food production outpacing the rate of population increase. Yet $20 \%$ of the Indian population would go undernourished as per the estimate of Indian Planning Commission in 2012 (Nayar, 2014). The repeated natural calamities as food and drought, poor cropping intensity. Lower return and profitability, poor and uneconomical land holding pattern and existing socio-politico-economic penury further aggravate the above problems (Damodaran et al., 2011). Poverty and paddy cultivation have become nearly synonymous worldwide where livestocks and crop diversification with commercial crops can be saviour from the situation (Damodaran et al., 2011).

The future of Indian Agriculture depends heavily on the development of appropriate farming system as applicable to resource poor farm families and as suited to different agro ecological zones. The endowment of abundant sunshine, long growing season, responsive soil types and combination of surface water, ground water and seasonal rains, above all a progressive presently, offer vast scope for an intensive farming system through multiple cropping and diversified farming including animal husbandry, forestry, sericulture, fisheries and the like (Patil et al., 2008). Radhamani et al., (2003) describes IFS as a component of farming system which takes in to account the concepts of minimizing risk, increasing production and profits which improving the utilization of organic wastes and crop residues.

Chhattisgarh is the $10^{\text {th }}$ largest state in India, with an area of $135,190 \mathrm{~km}^{2}$. Chhattisgarh is situated at Central part of India and location is $17^{\circ}-24^{\circ} \mathrm{N}$ and $80^{\circ} \cdot 40^{\prime}-83^{\circ} .38^{\prime}$ E. Chhattisgarh is constituted with 27 district. By population, it ranks as the $16^{\text {th }}$ most-populated state of the nation. It is an important electricity and steelproducing state of India. Chhattisgarh accounts for $15 \%$ of the total steel produced in the country. The Chhattisgarh state is agro climatically divided into three zones viz. Bastar plateau, Chhattisgarh plain and Northern Hills. Almost all the tuber crops are more or less grown in these three agro climatic zones. In Bastar plateau zone Cassava, Dioscorea, Colocasia (Arvi) and Sweet Potato; in Chhattisgarh plain Colocasia (Arvi), Amorphophallus and Sweet potato are under cultivation; whereas, in northern hills Sweet potato and Colocasia (Banda) are cultivated in large scale. Looking into the higher yield potential of the corps, its agro-climatic suitability and popularity among different zones of the state, an "All India Coordinated Research Projects on Tuber Crops (other than potato)" was sanctioned and established during the seventh five year plan at Indira Gandhi Krishi Vishwavidyalaya, Centre Jagdalpur with five mandatory crops Cassava, Colocasia, Dioscorea, Elephant foot yam and Sweet Potato in the year 1988.

Total area of tuber crops in Chhattisgarh is $2391.13 \mathrm{ha}$, total production is $64880.25 \mathrm{t}$ and average productivity of all tuber crops $22.70 \mathrm{t}$ which data were recorded though conventional survey from all 27 districts of Chhattisgarh during the year 2013-14. Raipur is the district with maximum Amorphophallus area (61.0 ha) and production (3440.40 t) followed by Mahasamund and Raigarh districts. Bastar is the district with having maximum area and production of Cassava (25.05 ha and $881.76 \mathrm{t}$ ), 
Colocasia/Arvi in Kharif season (77.05 ha and 2272.30 t), Greater yam (26.95 ha and 867.79 t), Sweet Potato (39.40 ha and $1103.20 \mathrm{t}$ ), Arial yam (10.09 ha and $263.75 \mathrm{t}$ ) and Kewkand (10.09 ha and 314.81t). In Kawardha district area of Summer Colocasia is 303.50 ha and production is $5857.55 \mathrm{t}$ under irrigated condition followed by Bastar and Jashpur. Summer colocasia in Kawardha district is mostly concentrated the river bank of Sankri River.

Surajpur district is the largest producer of Bunda (1607.58 t) in 46.80 ha area followed by Surguja and Balrampur during kharif season. Surguja is the district with maximum summer irrigated Bunda area (12.90 ha) and production (440.15 t). Bijapur district having maximum area and production of Curcuma angustifolia (10.97 ha and $284.56 \mathrm{t}$ ) followed by Dhamtari (10.87 ha and 223.75 t) and Kondagaon (8.83 ha and 223.75 ha. Kanker is the district with maximum other minor tuber crops area (6.55 ha) and production (79.13 t) followed by Rajnandgaon (4.40 ha) and Dhamtari (3.60 ha and 53.64 t) list of other minor tuber crops given in Table 3 . Dugukondal block of Kanker and Bhairamgarh block of Rajnandgaon districts were identified as special pockets for major growing area of Dioscorea esculanta during survey, Bastar division and Surguja for Curcuma agustifolia and Dioscorea floribunda, Nagari block of Dhamtari district for Dioscorea hispida, Pakhanjur block of Kanker for Swamp taro; Bastar-NarayanpurSukma-Damtewada districts for Dioscorea pentaphylla, Dioscorea spicata and Dioscorea rotundata (Shankar and Singh, 2018).

AICPRP on Tuber Crops, SGCARS, Kumhrawand, Jagdalpur under Tribal Sub Plan has conducted demonstrations on Tuber Crops based integrated farming system in Bastar and Kondagaon districts of Chhattisgarh.
Tuber crops based integrated farming system study (1.0 ha model)

Location - I: Village: Gumiyapal, Tokapal Block, Bastar District, Chhattisgarh State (N $19^{\circ} 07.181^{\prime}$ and E $81^{\circ} 50.905^{\prime} ; 506 \mathrm{msl}$ )

Year: 2012-2016

\section{Socio-economic profile before intervention}

Bastar District is a southern district of the state Chhattisgarh and Jagdalpur is the district headquarters. The district has an area of $8755.79 \mathrm{~km}^{2}$. Bastar District is bounded on the northwest by Rajnandgaon District, on the north by Kondagaon District, on the east by Nabarangpur and Koraput districts of Oridha state, on the south and southwest by Dantewada District, and on the west by Gadchiroli District of Maharashtra state. According to the 2011 census Bastar district has a population of $11,93,650$ in which more than $65 \%$ population $(7,87809$ schedule tribes $)$ belong to tribes like Maria, Muriya, Bhatra, Halba, Gond, Parja, Dhurva etc. The district has a population density of 140 inhabitants per square kilometre.

Rice is grown predominantly during kharif season as rainfed crop having 2.39 lakh hectare area but the productivity of this crop is very low $0.85 \mathrm{t} /$ ha in Bastar region of Chhattisgarh. The irrigated area is $1.67 \%$ and irrigation coverage is only 1.2 percent in the Bastar plateau whereas fertilizer use (4.6 kg/ha.) in the Bastar district are very less, which is insufficient to supply adequate nutrient to the crop. The pattern of livelihood in Bastar continues to be dictated by tradition. Even today, agricultural practices are traditional. Use of wooden ploughs is overwhelming while the number of iron ploughs is negligible. The same is true of bullock carts. The number of tractors is negligible while the bullock carts are all 
pervasive. The usage of traditional agricultural implements has lowered the production of agriculture. The kharif crops grown here are paddy, small millets, horse gram, urd, arhar, jowar and maize. The rabi crops include ramtil (niger), alsi, moong, mustard and gram. Collection and sale of forest produce and other forest-related work supplements meager agricultural incomes.

\section{Details of intervention}

The tuber crops based integrated farming system study (1.0 ha model) was laid out in 15 tribal farmer's field in Gumiyapal village in consecutive five years (2012-2016). Every year the farmers were changed. To enhance farmers food and nutrition security and livelihoods, the components were selected in such a way that sufficient production of carbohydrate, protein, minerals and vitamins. Further, farmers resources and needs also assessed before selecting the components. The components included are field crops (rice, maize and pigeonpea), tuber crops (elephant foot yam, colocasia (Arvi and Bunda, greater yam, aerial yam, sweet potato, tikhur and kewkanda). Vegetable crops (cowpea, Indian baen and okra), fish, poultry, ducks and fruit crops (papaya and banana). The area of each component was given in the Table 1 . In both the locations field preparation for the tuber crops based farming system was initiated with pre-monsoon rain. With the onset of monsoon (June second fortnight) planting/ sowing of various crop components initiated and completed within fifteen days. Method of planting, manures and fertilizer applications and intercultural operations were carried out as per recommended practices. The crops were harvested as and when matured. Broken and chaffy grains, the damaged and culled vegetables were chopped and fed to poultry, ducks and fish. The poultry was stall fed and ducks were allowed to feed in the open field. The gross income was calculated based on the total yield and market rate of the farm produce.

The results (mean of five years) of the tuber crops based integrated farming system revealed that elephant foot yam gave greater corm yield of $4356 \mathrm{~kg}$ and it was followed by colocasia (bunda) $3119 \mathrm{~kg}$, sweet potato 2664 $\mathrm{kg}$ and colocasia (arvi) $2423 \mathrm{~kg}$. The higher yield in the above crop was due to larger area they were cultivated ( $0.1 \mathrm{ha})$. Though rice was cultivated in same level of area ( $0.1 \mathrm{ha})$, the grain yield was just $251 \mathrm{~kg}$. The minor tuber crops tikhur and kewkand recorded 2027 and $1429 \mathrm{~kg}$, respectively in $0.05 \mathrm{ha}$, yield of Cassava $1301 \mathrm{~kg}$ tuber in 0.05 ha. Maize and pigeonpea cultivated in 0.02 and 0.03 ha recorded 94 and $63 \mathrm{~kg}$ respectively. The vegetable (cowpea, Indian bean and okra) recorded $721 \mathrm{~kg} / 0.05$ ha. Fish, poultry and duck registered 250, 112, and $67 \mathrm{~kg}$ meat respectively. The fruit crops (papaya and banana) gave $1149 \mathrm{~kg} / 0.05 \mathrm{ha}$. The gross and net returns from the tuber crops based integrated farming system were Rs 533110/and Rs 403720/-, respectively.

\section{Socio-economic profile after intervention}

After the intervention of tuber crops based integrated farming system in the farmer's field in Gumiyapal village, the farmers gross and net income increased to Rs 5,33,110/- and Rs 403720/ha, respectively. The increase in income was due to integration of tuber crops, fruit crops, fish, poultry and ducks along with cereals and pulses. The gross and net income increased 463 and $610 \%$ respectively after intervention of tuber crops based integrated farming system. The $\mathrm{B}$ : $\mathrm{C}$ ratio increased from 1.56 to 4.12 (Table 2). The employment generation increased from 199 to 261 man days. However, more than additional employment, spread of employment throughout the year was attained in tuber crops based integrated farming system. 
Table.1 The base line survey and farm household profile in the tribal village was conducted before taking up intervention

\begin{tabular}{|c|c|c|c|}
\hline S. No. & Details of Survey & : & Data Recorded \\
\hline 1. & Total households & : & 147 \\
\hline 2. & ST households & : & 129 \\
\hline 3. & Name of the tribe & : & Gond, Mariya, Bhatra and Halba \\
\hline 4. & Family size & : & 6.5 \\
\hline 5. & Land holding & : & 2.23 ha \\
\hline$\overline{6 .}$ & Crops/ Cropping system & : & $\begin{array}{l}\text { Rice, maize, sem, horse gram, colocasia, suran, sweet } \\
\text { potato, niger, cucurbits, toriya and minor tuber crops }\end{array}$ \\
\hline 7. & Annual income from agriculture & : & Rs $94630 /$ ha \\
\hline 8. & $\mathrm{~B}: \mathrm{C}$ ratio & : & 1.56 \\
\hline 9. & Employment & : & 199 man-days/ha \\
\hline
\end{tabular}

Table.2 Yield and economics of tuber crops based integrated farming system in Gumiyapal (Pooled mean of five years)

\begin{tabular}{|c|c|c|c|c|c|c|c|c|c|}
\hline $\begin{array}{l}\text { S. } \\
\text { No. }\end{array}$ & $\begin{array}{l}\text { Components } \\
\text { (Crop/Animal) }\end{array}$ & $\begin{array}{l}\text { Area } \\
\text { (ha) }\end{array}$ & $\begin{array}{l}\text { Yield } \\
\text { in } \\
(\mathrm{kg})\end{array}$ & $\begin{array}{l}\text { Price } \\
\text { Rs. } \\
\text { per kg. }\end{array}$ & $\begin{array}{l}\text { Gross } \\
\text { Income } \\
\text { (Rs.) }\end{array}$ & $\begin{array}{l}\text { Input } \\
\text { cost } \\
\text { (Rs.) }\end{array}$ & $\begin{array}{c}\text { Net } \\
\text { Income } \\
\text { (Rs.) }\end{array}$ & $\begin{array}{l}\text { B:C } \\
\text { Ratio }\end{array}$ & $\begin{array}{l}\text { Employment } \\
\text { Generation } \\
\text { (Mandays) }\end{array}$ \\
\hline 1. & Elephant foot yam & 0.10 & 4356 & 30 & 130680 & 26580 & 104100 & 4.92 & 26 \\
\hline 2. & Colocasia/Arvi & 0.10 & 2423 & 20 & 48460 & 16750 & 31710 & 2.89 & 23 \\
\hline 3. & Greater yam & 0.05 & 1335 & 20 & 26700 & 5970 & 20730 & 4.47 & 12 \\
\hline 4. & Aerial yam & 0.05 & 835 & 60 & 50100 & 9940 & 40160 & 5.04 & 10 \\
\hline 5. & Cassava & 0.05 & 1301 & 10 & 13010 & 3740 & 92703 & 3.48 & 11 \\
\hline 6. & Sweet Potato & 0.10 & 2664 & 15 & 39960 & 8710 & 31250 & 4.59 & 11 \\
\hline 7. & Colocasia (Bunda) & 0.10 & 3119 & 25 & 77980 & 18920 & 59060 & 4.12 & 27 \\
\hline 8. & $\begin{array}{l}\text { Tikhur (Curcuma } \\
\text { angustifolia Roxb.) }\end{array}$ & 0.05 & 2027 & 15 & 30400 & 7490 & 22910 & 4.06 & 15 \\
\hline 9. & $\begin{array}{l}\text { Kewkand (Costus } \\
\text { speciosus) }\end{array}$ & 0.05 & 1429 & 10 & 14290 & 4340 & 9950 & 3.29 & 12 \\
\hline 10. & Rice & 0.10 & 251 & 20 & 5020 & 1330 & 3690 & 3.77 & 21 \\
\hline 11. & Maize & 0.02 & 94 & 10 & 940 & 260 & 680 & 3.61 & 2 \\
\hline 12. & Pigeon Pea & 0.03 & 63 & 55 & 3470 & 880 & 2590 & 3.94 & 5 \\
\hline 13. & $\begin{array}{l}\text { Vegetable component } \\
\text { (Cow pea, Indian bean } \\
\text { \& Okra) }\end{array}$ & 0.05 & 721 & 25 & 18030 & 7980 & 10050 & 2.26 & 10 \\
\hline 14. & Fish & 0.10 & 250 & 105 & 26250 & 5710 & 20540 & 4.60 & 22 \\
\hline 15. & Poultry & 75 Nos. & 112 & 150 & 16800 & 3490 & 13310 & 4.81 & 27 \\
\hline 16. & Ducks & 45 Nos. & 67 & 120 & 8040 & 1750 & 6290 & 4.59 & 17 \\
\hline 17. & $\begin{array}{l}\text { Fruits (Papaya \& } \\
\text { Banana) }\end{array}$ & 0.05 & 1149 & 20 & 22980 & 5550 & 17430 & 4.14 & 10 \\
\hline & Total & 1.0 & 22196 & - & 533110 & 129390 & 403720 & 4.12 & 261 \\
\hline
\end{tabular}


Table.3 Socio-economic conditions of the farmer before and after intervention at Village-Gumiyapal

\begin{tabular}{|c|l|c|c|c|c|c|}
\hline $\begin{array}{c}\text { S. } \\
\text { No. }\end{array}$ & \multicolumn{1}{|c|}{ Particular } & $\begin{array}{c}\text { Gross income } \\
\text { (Rs/ha) }\end{array}$ & $\begin{array}{c}\text { Expenditure } \\
\text { (Rs/ha) }\end{array}$ & $\begin{array}{c}\text { Net income } \\
\text { (Rs/ha) }\end{array}$ & $\begin{array}{c}\text { B: C } \\
\text { ratio }\end{array}$ & $\begin{array}{c}\text { Employment generation } \\
\text { (man-days/ha) }\end{array}$ \\
\hline 1. & Before intervention & 94630 & 37780 & 56850 & 1.56 & 199 \\
\hline 2. & After intervention & 533110 & 129390 & 403720 & 4.12 & 261 \\
\hline
\end{tabular}

Table.4 The base line survey and farm household profile in the tribal village was conducted before taking up intervention

\begin{tabular}{|c|l|l|l|}
\hline S. No. & \multicolumn{1}{|c|}{ Details of Survey } & $:$ & \multicolumn{1}{|c|}{ Data Recorded } \\
\hline 1. & Total households & $:$ & 203 \\
\hline 2. & ST households & $:$ & 118 \\
\hline 3. & Name of the tribe & $:$ & Gond, Maria and Halba \\
\hline 4. & Family size & $:$ & 7.30 \\
\hline 5. & Land holding & $:$ & 2.23 ha \\
\hline 6. & Crops/ Cropping system & $:$ & $\begin{array}{l}\text { Rice, sweet potato, tomato, black gram, arhar, } \\
\text { cowpea, niger, toriya, turmeric, greater yam and } \\
\text { minor tuber crops }\end{array}$ \\
\hline 7. & Annual income from agriculture & $:$ & Rs 106300/ha \\
\hline 8. & B: C ratio & $:$ & 2.18 \\
\hline 9. & Employment & $:$ & 203 man-days/ha \\
\hline
\end{tabular}

Table.5 Yield and economics of tuber crops based integrated farming system in Village: Tatirash (Pooled mean of five years)

\begin{tabular}{|c|c|c|c|c|c|c|c|c|c|}
\hline $\begin{array}{l}\text { S. } \\
\text { No. }\end{array}$ & Components (Crop/Animal) & $\begin{array}{c}\text { Area } \\
\text { (ha) }\end{array}$ & $\begin{array}{l}\text { Yield } \\
\text { in }(\mathbf{k g})\end{array}$ & $\begin{array}{c}\text { Price } \\
\text { Rs. per } \\
\text { kg. }\end{array}$ & $\begin{array}{l}\text { Gross } \\
\text { Income } \\
\text { (Rs.) }\end{array}$ & $\begin{array}{c}\text { Input } \\
\text { cost } \\
\text { (Rs.) }\end{array}$ & $\begin{array}{c}\text { Net } \\
\text { Income } \\
\text { (Rs.) }\end{array}$ & $\begin{array}{l}\text { B:C } \\
\text { Ratio }\end{array}$ & $\begin{array}{l}\text { Employment } \\
\text { Generation } \\
\text { (Mandays) }\end{array}$ \\
\hline 1. & Elephant foot yam & 0.10 & 4359 & 30 & 130770 & 25840 & 104930 & 5.06 & 25 \\
\hline 2. & Colocasia/Arvi & 0.10 & 2432 & 20 & 48640 & 16780 & 31860 & 2.90 & 23 \\
\hline 3. & Greater yam & 0.05 & 1379 & 20 & 27580 & 5980 & 21600 & 4.61 & 12 \\
\hline 4. & Aerial yam & 0.05 & 822 & 60 & 49320 & 10070 & 39250 & 4.90 & 12 \\
\hline 5. & Cassava & 0.05 & 1379 & 10 & 13790 & 4190 & 9600 & 3.29 & 12 \\
\hline 6. & Sweet Potato & 0.10 & 2540 & 15 & 38100 & 9340 & 28760 & 4.08 & 11 \\
\hline 7. & Colocasia (Bunda) & 0.10 & 3069 & 25 & 76730 & 19130 & 57600 & 4.01 & 27 \\
\hline 8. & Tikhur (Curcuma angustifolia Roxb.) & 0.05 & 1918 & 15 & 28770 & 7530 & 21240 & 3.82 & 15 \\
\hline 9. & Kewkand (Costus speciosus) & 0.05 & 1357 & 10 & 13570 & 4460 & 9110 & 3.04 & 13 \\
\hline 10. & Rice & 0.10 & 252 & 20 & 5040 & 1330 & 3710 & 3.79 & 21 \\
\hline 11. & Maize & 0.02 & 96 & 10 & 960 & 270 & 690 & 3.56 & 2 \\
\hline 12. & Pigeon Pea & 0.03 & 62 & 55 & 3410 & 910 & 2500 & 3.75 & 4 \\
\hline 13. & $\begin{array}{l}\text { Vegetable component (Cow pea, } \\
\text { Indian Bean \& Okra) }\end{array}$ & 0.05 & 740 & 25 & 18500 & 8180 & 10320 & 2.26 & 11 \\
\hline 14. & Fish & 0.10 & 250 & 105 & 26250 & 5760 & 20490 & 4.56 & 23 \\
\hline 15. & Poultry & 75 Nos. & 109 & 150 & 16350 & 3480 & 12870 & 4.70 & 26 \\
\hline 16. & Ducks & 45 Nos. & 62 & 120 & 7440 & 1750 & 5690 & 4.25 & 17 \\
\hline 17. & Fruits (Papaya \& Banana) & 0.05 & 1172 & 20 & 23440 & 5700 & 17740 & 4.11 & 9 \\
\hline & Total/A verage* & 1.0 & 21998 & - & 528660 & 130700 & 397960 & 4.04 & 263 \\
\hline
\end{tabular}


Table.6 Socio-economic conditions of the farmer before and after intervention

\begin{tabular}{|c|c|c|c|c|c|c|}
\hline $\begin{array}{c}\text { S. } \\
\text { No. }\end{array}$ & Particular & $\begin{array}{c}\text { Gross Income } \\
\text { (Rs/ha) }\end{array}$ & $\begin{array}{c}\text { Expenditure } \\
\text { (Rs/ha) }\end{array}$ & $\begin{array}{c}\text { Net income } \\
\text { (Rs/ha) }\end{array}$ & $\begin{array}{c}\text { B: C } \\
\text { ratio }\end{array}$ & $\begin{array}{c}\text { Employment generation } \\
\text { (man-days/ha) }\end{array}$ \\
\hline $\mathbf{1}$ & Before intervention & 106300 & 33570 & 72730 & 2.18 & 203 \\
\hline $\mathbf{2}$ & After intervention & 528660 & 130700 & 397960 & 4.04 & 263 \\
\hline
\end{tabular}

Part of the yields of grains, tuber crops, vegetables, fruits, egg, meat and fish were sold for cash income. By marketing of vegetable, tubers, fruits, egg, fish and meat a farmer is able to earn sufficient money to meet out daily needs. Further, the availability of tubers for household consumption for long period due to high storability along with other vegetables, rice, fish, egg and meat enhanced food and nutritional security of the household. The cash income improved the livelihoods of the farm families.

Location - II: Village: Tatirash, Keshkal Block, Kondagaon District, Chhattisgarh State (N $19^{\circ} 59.961^{\prime}$ and E $081^{\circ} 35.427 ' ; 644$ $\mathrm{msl}$ )

Year: 2012-2016

\section{Socio-economic profile before intervention}

Kondagaon District is a southern district of the state Chhattisgarh and Kondagaon also is the district headquarter. The district has an area of $7768.907 \mathrm{~km}^{2}$. Kondagaon District is bounded on the northwest by Narayanpur District, on the north by Kanker District, on the east by Nabarangpur and Koraput districts of Oridha state, on the south and southwest by Bastar District, and on the west by Gadchiroli District of Maharashtra state (Table 5). According to the 2016 census Kondagaon district has a population of 5,78,326 in which more than $65 \%$ population $(3,75,912$ schedule tribes) belong to tribes like Maria, Muriya, Bhatra, Halba, Gond etc. The district has a population density of 75 inhabitants per square kilometre.

\section{Details of intervention}

The Tuber Crops Based Farming System study (1.0 ha model) was laid out in 15 tribal farmer's field in each village in consecutive five years (2012-2016). Every year the farmers were changed. To enhance farmers food and nutrition security and livelihoods, the components were selected in such a way that sufficient production of carbohydrate, protein, minerals and vitamins. Further farmers resources and needs also assessed before selecting the components. The components included are field crops (rice, maize and pigeonpea), tuber crops (elephant foot yam, colocasia (arvi and bunda), greater yam, aerial yam, sweet potato, tikhur and kewkanda) Vegetable crops (cowpea, Indian baen and okra), fish, poultry, ducks and fruit crops (papaya and banana). The area of each component was given in the Table 3. In both the locations field preparation for the tuber crops based farming system was initiated with pre-monsoon rain. With the onset of monsoon (June second fortnight) planting/ sowing of various crop components initiated and completed within fifteen days. Method of planting, manures and fertilizer applications and intercultural operations were carried out as per recommended practices. The crops were harvested as and when matured. Broken and chaffy grains, the damaged and culled vegetables were chopped and fed to poultry, ducks and fish. The poultry was stall fed and ducks were allowed to feed in the open field. The gross income was calculated based on the total yield and market rate of the farm produce.

The results (mean of five years) of the tuber 
crops based integrated farming system revealed that elephant foot yam gave greater corm yield of $4359 \mathrm{~kg}$ and it was followed by colocasia (bunda) $3069 \mathrm{~kg}$, sweet potato 2540 $\mathrm{kg}$ and colocasia (arvi) $2432 \mathrm{~kg}$. The higher yield in the above crop was due to larger area they were cultivated $(0.1$ ha). Though rice was cultivated in same level of area ( $0.1 \mathrm{ha})$, the grain yield was just $252 \mathrm{~kg}$. The minor tuber crops tikhur and kewkand recorded 1918 and $1357 \mathrm{~kg}$, respectively in 0.05 ha. Cassava yielded $1379 \mathrm{~kg}$ tuber/0.05 ha. Maize and pigeonpea cultivated in 0.02 and 0.03 ha recorded 96and $62 \mathrm{~kg}$ respectively. The vegetable (cowpea, Indian bean and okra) recorded $740 \mathrm{~kg} / 0.05$ ha. Fish, poultry and duck registered 250, 109, and $62 \mathrm{~kg}$ meat respectively. The fruit crops (papaya and banana) gave $1172 \mathrm{~kg} / 0.05 \mathrm{ha}$. The gross and net returns from the tuber crops based farming system were Rs 528660/- and Rs 397960/-, respectively.

\section{Socio-economic profile after intervention}

After the intervention of tuber crops based integrated farming system in the farmer's field in Tatirash village, the farmers gross and net income increased to Rs 5,28,660/- and Rs $3,97,960 /$ ha, respectively. The increase in income was due to integration of tuber crops, fruit crops, fish, poultry and ducks along with cereals and pulses. The gross and net income increased 397 and $447 \%$ respectively after intervention of tuber crops based integrated farming system. The $\mathrm{B}$ : $\mathrm{C}$ ratio increased from 2.18 to 4.04 (Table 4). The employment generation increased from 203 to 263 man days. However, more than additional employment, spread of employment throughout the year was attained in tuber crops based integrated farming system.

Part of the yields of grains, tuber crops, vegetables, fruits, egg, meat and fish were sold for cash income. By marketing of vegetable, tubers, fruits, egg, fish and meat a farmer is able to earn sufficient money to meet out daily needs. Further, the availability of tubers for household consumption for long period due to high storability along with other vegetables, rice, fish, egg and meat enhanced food and nutritional security of the household. The cash income improved the livelihoods of the farm families.

Tuber crops based farming system is an integrated approach to farming as compared to monoculture. This model could increase land productivity, income of the farmers, balance nutrition, employment and sustainability of the farmer. This could be a model to attract and retain present generation farmers who are very migrating to urban areas. However, we need to frame policies to help the small farmers to diversify their activities towards both on-farm and off-farm activities for enhanced sustainability and productivity. The model developed has the potential to transform the tribal region of Chhattisgarh, especially the Bastar and Kondagaon districts.

\section{Acknowledgement}

The authors express their sincere gratitude to Dr. James George, Project Coordinator, ICAR-AICRP on Tuber Crops for encouragement and undertaking this programme. Authors express their sincere gratitude to ICAR-AICRP on Tuber Crops for undertaking the work under the project and facilities provided. The senior author is indebted to Dr. S. C. Mukherjee, Dean, SG CARS, and Jagdalpur for their valuable suggestions and guidance during the studies.

\section{References}

Damodaran, T., Ravi, R.B., Mishra, V, K., Sharma, D.K., Ram, R.A., Ravi, S. and Kumar, H. 2011. Integrated farming 
system and livelihood security-an approach. Central Soil Salinity Research Institute, Regional Research Station, Liuchow, India, pp.106.

Nayar, N. M. 2014. The contribution of tropical tuber crops towards food security. J. Root Crops, 40 (1): 3-14.

Patil, H. M., Todmal, S.M., Patil, V.S., Wani, A.G. and Gaikwad, C.B. 2008. Farming systems approach for achieving sustainable agriculture. In: proceedings of National Symposium on New Paradigms in Agronomic Research.
Indian Society of Agronomy. Navsari Agriculture University, Gujarat. pp 292293.

Radhamani, S., Balasubramanian, A., Ramamoorthy, K. and Geetalakshmi, V. 2003. Sustainable integrated farming systems for dry lands: A review. Agric. Rev, 24: 204-2010.

Shankar, D. and Singh, J. 2018. Tropical Tuber Crops Potential and Prospects, Book Chapter: Tuber Crops of Chhattisgarh. pp. 227-262.

\section{How to cite this article:}

Deo Shankar, Chetna Banjare and Sahu, M.K. 2018. Tuber Crops Based Integrated Farming System Studies in Bastar and Kondagaon Districts of Chhattisgarh. Int.J.Curr.Microbiol.App.Sci. 7(09): 1650-1658. doi: https://doi.org/10.20546/ijcmas.2018.709.199 